\title{
Micro-Computed Tomographic Analysis of Apical Foramen Enlargement of Mature Teeth: A Cadaveric Study
}

\author{
Análisis Mediante Micro-CT del Ensanchamiento del Foramen \\ Apical de Dientes Maduros: un Estudio Cadavérico
}

\author{
Cristina Bucchi'1,2; Josep Maria de Anta $^{3}$ \& María Cristina Manzanares-Céspedes ${ }^{3}$
}

BUCCHI, C.; DE ANTA, J. M. \& MANZANARES-CÉSPEDES, M. C. Micro-computed tomographic analysis of apical foramen enlargement of mature teeth: a cadaveric study. Int. J. Odontostomat., 14(2):177-182, 2020.

\begin{abstract}
Revitalization procedures have been extensively studied during the last decade and offers several advantages over root canal treatment, such as the recovery of the natural immune system. Mature teeth have a small apical foramen diameter (AFD), which could impair the ingrowth of tissue into the root canal. We analysed three methods for apical foramen enlargement by instrumentation in in situ human teeth and evaluated the damage over hard tissues produced by the techniques. Tooth length $(\mathrm{TL})$, defined as the length from the most coronal part of the crown to the point at which the file abandons the root canal, was calculated. Forty-four in situ teeth were randomized: Group I: instrumentation $0.5 \mathrm{~mm}$ coronal to TL; Group II: at TL level; Group III: $0.5 \mathrm{~mm}$ beyond TL. Teeth were instrumented up to K-file \#80. The mandibles were scanned in a micro-CT device before and after treatment. Group I: Only $20 \%$ of teeth presented an enlarged AFD, with augmentation of $0.09 \mathrm{~mm}$. No damage to hard tissues was observed. Group II: $71.4 \%$ of the teeth presented an enlarged AFD with augmentation of $0.42 \mathrm{~mm} .35 .7 \%$ presented damage to periapical tissues. Group III: $86.7 \%$ presented an enlarged AFD with augmentation of $0.43 \mathrm{~mm}$. $46.7 \%$ presented damage to periapical tissues. All groups presented similar prevalence of teeth with dentine thickness less than $1 \mathrm{~mm}$. All mandibular incisors presented areas of thickness less than $1 \mathrm{~mm}$. Instrumentation $0.5 \mathrm{~mm}$ beyond TL is the most effective technique.
\end{abstract}

KEY WORDS: regenerative endodontics; revitalization; mature teeth; apical foramen enlargement.

\section{INTRODUCTION}

Currently, the most reliable option for the treatment of necrotic or irreversibly inflamed mature teeth is still root canal treatment. However, endodontically treated teeth are susceptible to reinfections and fractures, and the failure rate is close to $25 \%$ at 3-5 years ( $\mathrm{He}$ et al., 2017). Moreover, endodontically treated teeth will remain devitalized after treatment throughout the patient's lifetime.

Revitalization procedures producing positive clinical outcomes have been extensively studied in recent decades (Lolato et al., 2016; del Fabbro et al., 2016; Lin et al., 2017; Meschi et al., 2018). Teeth revitalization offers several advantages over conventional root canal treatment, such as the recovery of the natural immune system and a structurally more resistant tooth (Sedgley \& Messer, 1992; Lin et al.) Regenerative approaches for treatment of pulp necrosis have been mainly studied and applied in immature teeth. One of the reasons for this, is the absence of an apical constriction in immature teeth; this would enhance the entrance of cells, growth factors and blood vessels, favouring the neoformation of tissue into the root canal (Murray et al., 2007). Mature teeth in contrast have a very small apical foramen diameter (Bucchi et al., 2017), making the achievement of pulp regeneration or repair a greater clinical challenge.

To date it is unclear whether a wide apical foramen would enhance the possibilities of tooth

${ }^{1} \mathrm{PhD}$ Program in Medicine and Translational Research, Universitat de Barcelona, Barcelona, Spain. cristina.bucchifrontera.cl, ORCID: 0000-0003-3838-1227.

2 Department of Integral Adult Dentistry, Research Center for Dental Sciences (CICO), Dental School, Universidad de La Frontera, Temuco, Chile.

${ }^{3}$ Human Anatomy and Embryology Unit. Department of Pathology and Experimental Therapeutics, Universitat de Barcelona, Barcelona, Spain. janta@.ub.edu, ORCID: 0000-0003-3499-8297, mcmanzanares@ub.edu, ORCID: 0000-0002-4585-4953. 
revascularization, in view of the contradictory results reported in the last few years (Laureys et al., 2013; Estefan et al., 2016) and the relatively low amount of research on this topic. However, previous studies have reported that a larger apical foramen improved regenerative endodontics outcomes (Estefan et al.), favoured a more rapid radiographic repair of apical periodontitis (Jara et al., 2018) and enhanced root canal disinfection (Rodrigues et al., 2017).

Case reports and animal studies published in recent years describe attempts to revascularize mature teeth using a regenerative approach (Laureys et al.; Paryani \& Kim, 2013; Saoud et al., 2016; Xu \& Li, 2018; Bucchi et al., 2019) with variable results. These studies used different methods for apical foramen enlargement, thus there are variations in working length and widening of the file, among other parameters. Methods for apical foramen enlargement are poorly described in the literature. Considering that the location of the apical foramen may vary depending on several factors (ElAyouti et al., 2014), that it is not possible to determine the exact location of the foramen using the current available technology (Estefan et al.), and that a variation of only $0.5 \mathrm{~mm}$ in working length may result in ineffective widening of the apical foramen (Bucchi et al., 2017), there is a need to establish a standardized clinical protocol for foramen widening. Thus, as the major apical foramen is a structure not identifiable by radiography, we propose a standardised methodology to ensure the apical foramen enlargement based on the point at which the file radiographically abandons the root canal.

The objects of the present study were to evaluate the effectiveness of apical foramen enlargement in in situ human teeth by instrumentation with different three working lengths, and to compare the damage to hard tissues (dentine microcracks and invasion of periapical bone by over-instrumentation) in each group using micro-CT.

\section{MATERIAL AND METHOD}

The project was approved by the Bioethics Commission of the University of Barcelona $\left(\mathrm{n}^{\circ}\right.$ 00003099). Seven wet mandibles containing 4-10 uniradicular teeth were selected from the collection of the Body Donation Service and Dissection Room of the University of Barcelona. The sample size was 44 in situ human teeth. Only mature incisors, canines and premolars were included, and in the case of bi-radicular teeth only one canal per tooth was instrumented. Teeth with obliterated root canal, external or internal resorption, caries, presence of filling materials, posts or root fractures and/or dilacerated teeth were excluded.

Throughout the procedure the human mandibles were kept wet in $1 \%$ formaldehyde. Before treatment, each mandible/maxilla was scanned in a micro-CT device (Quantum FX mCT, PerkinEImer, Health Sciences, Massachusetts, USA). Briefly, the samples were scanned at $90 \mathrm{kV}$ and $160 \mathrm{~mA}$ through FOV 40$60 \mathrm{~mm}$, exposure time 4.5 minutes (voxel size of $118 \times 118 \times 118 \mu \mathrm{m})$. The acquired images were reconstructed into cross-sectional slices with PerkinElmer software (PerkinElmer, Health Sciences, Massachusetts, USA) using the Feldkamp method.

Crown access was created under constant irrigation and the pulp chamber was located. Pulp tissue was extracted with a K- Flexofile \#15 (Dentsply Maillefer, Ballaigues, Switzerland), the teeth were radiographed with a digital radiograph system (Dexco ADX6000, Pasadena, USA) and tooth length (TL), defined as the length from the most coronal part of the crown to the point at which the file radiographically abandons the root canal, was calculated. The cone was located perpendicular to the tooth axis and x-ray film.

The teeth were randomly assigned to one of the groups using a randomizer website (researchrandomizer.org):

Group I ( $n=15)$ : working length TL $-0.5 \mathrm{~mm}$ (subinstrumentation)

Group II $(n=14)$ : working length to the level of apical foramen

Group III $(n=15)$ : working length TL $+0.5 \mathrm{~mm}$ (overinstrumentation)

Teeth were manually instrumented with a $25 \mathrm{~mm}$ K-file\#15 progressing up to K-file\#80 (SybronEndo, California, USA), using the balanced force technique under copious irrigation with $2.5 \%$ sodium hypochlorite. Files were renewed after instrumentation of 10 teeth. After instrumentation the samples were again scanned with micro-CT, as previously described.

The reconstructed image stacks of the bone blocks before and after canal instrumentation were co- 
registered using the OsiriX DICOM Viewer v. 9.0 software (Pixmeo DARL, Geneva, Switzerland) for threedimensional visualization and qualitative analysis of the teeth. Transversal, sagittal and coronal section images of each tooth were screened by a previously calibrated examiner who was blinded to the experimental groups. Screening was intended to identify invasion of the periapical bone by the instrumentation (which was defined as the loss of the continuity of the apical cortical bone), dimension of the apical foramen diameter before and after treatment, and posttreatment thickness of the dentine walls. The thickness of the dentine walls was measured $3 \mathrm{~mm}$ above the apex, and from the inner border to the outer border of the dentine wall. Only the minimum values of wall thickness were recorded. Outcomes were measured twice ( 7 days between the first and the second measurements). The intra-observer agreement was calculated using Kappa coefficient by means of SPPS 20.0 software.

Statistical analysis: The data collected were entered into an Excel file and statistical analysis was performed by SPSS software (V. 20.0, Chicago, USA). Descriptive statistics were calculated, including means and standard deviation. Data distribution analysis was carried out by means of the Shapiro-Wilkes test. Pearson's Chi-squared, Fisher Exact and Wilcoxon Signed Rank tests were used to evaluate statistical differences. For all statistical analyses a significance level less than 0.05 was used.

\section{RESULTS}

The mean pre-treatment apical foramen diameter was $0.24( \pm 0.09)$, ranging from 0.1 to $0.34 \mathrm{~mm}$ (Table I), with no statistical differences between groups.
Group I sub-instrumented teeth. Only $20 \%$ of teeth presented an enlarged apical foramen diameter. Moreover, the augmentation was only $0.09 \mathrm{~mm}$, with a final apical foramen diameter (AFD) of $0.32( \pm 0.24)$. According to the Wilcoxon Signed Rank test, pretreatment and post-treatment foramen diameters were similar $(p>0.05)$ (Table I). No teeth presented damage to periapical hard tissues. $33 \%$ of teeth presented areas of dentine thickness of less than $1 \mathrm{~mm}$.

Group II instrumentation at TL level: Most of the teeth $(71.4 \%)$ presented an enlarged apical foramen diameter. Moreover, the diameter was augmented by $0.42 \mathrm{~mm}$, with a final AFD of $0.68 \mathrm{~mm}( \pm 0.38)$. According to the Wilcoxon Signed Rank test, pre-treatment and post-treatment foramen diameters were statistically different $(p<0.05)$ (Table I). $35.7 \%$ of the samples presented damage to periapical hard tissues (Fig. 1A). $50 \%$ of teeth presented areas of dentine thickness of less than $1 \mathrm{~mm}$.

Group III over-instrumentation: Most teeth (86.7 \%) presented an enlarged apical foramen diameter (Fig. $2 \mathrm{~A}, \mathrm{~B})$. Moreover, the diameter was augmented by $0.43 \mathrm{~mm}$, with a final AFD of $0.68 \mathrm{~mm}( \pm 0.21)$. According to the Wilcoxon Signed Rank test, pretreatment and post-treatment foramen diameters were statistically different $(p<0.05)$ (Table I). $46.7 \%$ presented damage to periapical hard tissues (Fig. 1A). There were two teeth in which the apical foramina were not enlarged due to apical transportation (Fig. 2 A, B). $40 \%$ of teeth presented areas of dentine thickness of less than $1 \mathrm{~mm}$.

Comparison among groups: Teeth from the overinstrumented group presented a higher percentage of teeth with an enlarged apical foramen compared to Groups I and II $(p<0.05)$. However, they also presented a major prevalence of damage to periapical hard tissues $(p<0.05)$. Similar prevalence of dentine thickness of less than $1 \mathrm{~mm}$ was observed between

Table I. Distribution of foramen sizes before and after treatment, by experimental group.

\begin{tabular}{|c|c|c|c|c|}
\hline Group & & $\begin{array}{l}\text { Sub-instrumentation } \\
\text { (n) }\end{array}$ & $\begin{array}{l}\text { At apex } \\
\text { level }(n)\end{array}$ & $\begin{array}{l}\text { Over-instrumentation } \\
\text { (n) }\end{array}$ \\
\hline \multirow{5}{*}{$\begin{array}{l}\text { Apical foramen } \\
\text { diameter before } \\
\text { treatment }(\mathrm{mm})\end{array}$} & $0.0-0.2$ & 8 & 8 & 3 \\
\hline & $0.21-0.4$ & 7 & 6 & 12 \\
\hline & $0.41-0.6$ & 0 & 0 & 0 \\
\hline & $0.61-0.8$ & 0 & 0 & 0 \\
\hline & $<0.81$ & 0 & 0 & 0 \\
\hline \multirow{5}{*}{$\begin{array}{l}\text { Apical foramen } \\
\text { diameter after } \\
\text { treatment }(\mathrm{mm})\end{array}$} & $0.0-0.2$ & 7 & 3 & 0 \\
\hline & $0.21-0.4$ & 5 & 1 & 3 \\
\hline & $0.41-0.6$ & 0 & 2 & 0 \\
\hline & $0.61-0.8$ & 3 & 4 & 10 \\
\hline & $<0.81$ & 0 & 4 & 2 \\
\hline
\end{tabular}



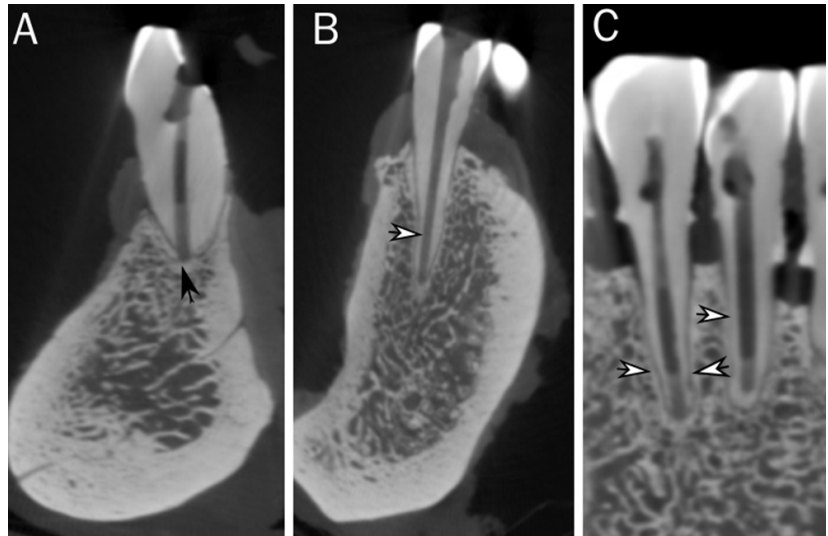

Fig. 1. Sagittal views of over-instrumented teeth (Group III) $(A-C)$. Invasion of the periapical bone is observed (B, black arrow), as well as reduced width of the dentine walls in the apical third of the tooth (B \& $\mathrm{C}$ white arrows).
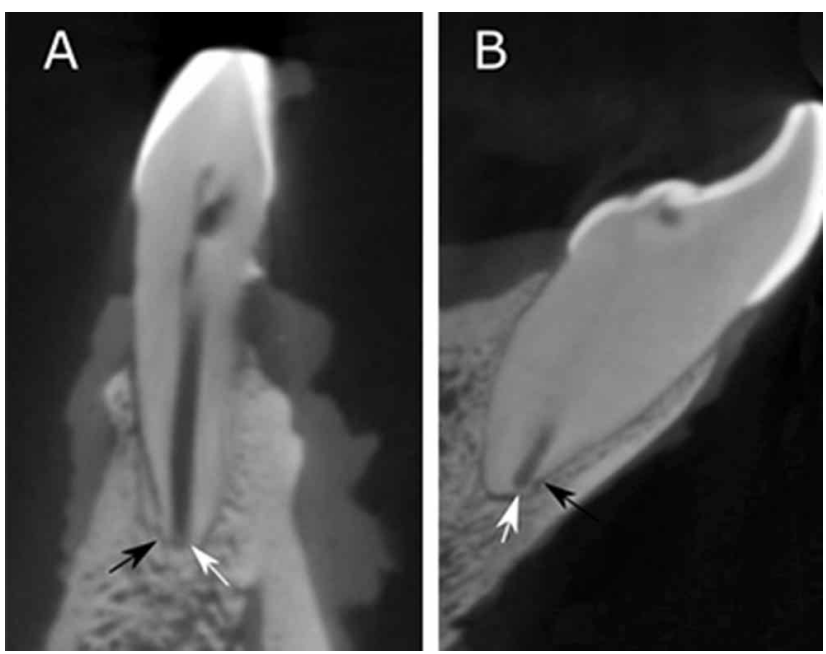

Fig. 2. Sagittal view of an over-instrumented tooth (Group III) (A \& B). Apical transportation is observed (white arrows) which prevented enlargement of the apical foramen (black arrows). groups (Table II). However, differences in these parameters were observed when analysed by tooth type. $100 \%$ of mandibular incisors presented areas in which the dentine wall presented a thickness of less than $1 \mathrm{~mm}$. The second most affected teeth were mandibular premolars, while no maxillary incisors presented wall thickness of less than $1 \mathrm{~mm}$ (Table II).

\section{DISCUSSION}

The new approach for the treatment of necrotic or irreversibly inflamed pulps attempts to repair/ regenerate pulp tissue using the patient's own potential for angiogenesis and the presence of stem cells and growth factors in the periapical and dental tissues (Galler et al., 2016; Galler \& Widbiller, 2017; Widbiller et al., 2017). However, it is necessary for the clinician to provide an appropriate tooth environment to enhance revitalization. Mature teeth present a small apical diameter (Bucchi et al., 2017) which acts as a physical barrier, hindering access by the biological factors to enhance regeneration of the pulp tissue that occupies the entire root canal (Estefan et al.).

Foramen enlargement is the intentional and mechanical enlargement of the apical foramen (Yaylali et al. 2017). It has been mainly performed to reduce the bacterial load by excising the infected cementum and dentin in necrotic teeth with apical pathosis (Yaylali et al.) and induce periapical tissue repair (de Souza Filho et al. 1987), although for regenerative endodontics also represent an additional benefit, as is to allow the ingrowth of new tissue into the root canal (Murray et al.). Thus, intentional enlargement of the apical foramen may be necessary from a regenerative

Table II. Number of teeth with a dentine thickness less than $1 \mathrm{~mm}$, distributed by treatment group and by tooth type.

\begin{tabular}{lcc}
\hline Group & $\begin{array}{l}\text { N (\%) teeth with } \\
\text { dentin walls <1 mm }\end{array}$ & $\begin{array}{l}\text { Mean (sd) of the dentine walls thickness } \\
\text { (out of walls with thickness less than 1 mm) }\end{array}$ \\
\hline Sub-instrumentation (group I) & $5(33.3 \%)$ & $0.53(0.17)$ \\
At apex level (group II) & $7(50 \%)$ & $0.72(0.20)$ \\
Over-instrumentation (group III) & $6(40 \%)$ & $0.60(0.19)$ \\
Mandibular premolars (of all groups) & $6(60 \%)$ & $0.59 \mathrm{~mm}(0.19)$ \\
Maxillary premolars (of all groups) & $3(42.9 \%)$ & $0.77 \mathrm{~mm}(0.08)$ \\
Mandibular canines (of all groups) & $2(50 \%)$ & $0.89 \mathrm{~mm}(0.03$ \\
Maxillary canines (of all groups) & $2(33.3 \%)$ & $0.76 \mathrm{~mm}(0.16)$ \\
Mandibular incisors (of all groups) & $5(100 \%)^{*}$ & $0.45 \mathrm{~mm}(0.1)$ \\
Maxillary incisors (of all groups) & $0(0 \%)^{*}$ & 0 \\
\hline
\end{tabular}

*Statistically significant differences. 
microbiological viewpoint. Therefore, we aimed to establish a standardized method to achieve apical foramen widening of mature teeth in cadaveric material. Being performed over in situ teeth, this study provides reliable evidence with clinical application for an effective apical foramen enlargement.

We are not able to identify the exact position of the apical foramen with current technology. Electronic locators and computerized axial tomography are the most promising options. However at present these devices are neither completely precise (Lucena et al., 2014; Tsesis et al., 2015) nor always available in clinical practice. A previous study (Bucchi et al., 2017) showed that a variation of only $0.5 \mathrm{~mm}$ in working length alters the effectiveness of apical foramen enlargement procedures, which coincides with our results. Instrumentation $0.5 \mathrm{~mm}$ short of the apical foramen resulted in widening of the foramen by only $0.09 \mathrm{~mm}$, while instrumentation $0.5 \mathrm{~mm}$ beyond the apical foramen resulted in widening of $0.42 \mathrm{~mm}$. Moreover, it is essential to consider the patient's discomfort (Yaylali et al.) and the clinical complications that overinstrumentation could cause, and especially the risk of apical extrusion of intracanal bacteria (Kus, tarci et al., 2008) and debris (Siqueira Jr. et al., 2003).

Instrumentation with large files can result in iatrogenic damage such as dentinal cracks, weakening of the dentine walls, damage to periapical bone tissue and apical transportation (Olivieri et al., 2014; Bucchi et al., 2017). In this study, two teeth in the overinstrumentation group presented apical transportation, which prevented foramen enlargement. Instrumentation was carried out with wide stainless-steel files (\#80), whereas working with nickel-titanium rotary instruments could have improved these outcomes (Ceyhanli et al., 2014), as well as diminishing the prevalence of dentinal cracks (Wei et al., 2017). Another complication of instrumentation with wide files (\#80) is weakening of the dentine walls. In this study $100 \%$ of mandibular incisors and $40.9 \%$ of all teeth presented at least one area with dentine wall thickness of less than $1 \mathrm{~mm}$. Although this may represent an issue, if the patient needs further prosthetic rehabilitation treatment, the potential of hard tissue formation adhered to the dentine walls after the regenerative endodontic approach (Lolato et al.; del Fabbro et al.) can overcome this disadvantage. Prior analysis of dentine wall thickness before treatment is highly recommended, particularly in mandibular incisors and premolars; this will also allow the possibility of establishing different foramen sizes by tooth type to be assessed.
Instrumentation $0.5 \mathrm{~mm}$ beyond the apical foramen is the most effective technique for apical foramen enlargement. However, it is important to consider the effect of this technique on periapical bone and weakening of the dentine wall. Study of its effects in vivo is also needed.

BUCCHI, C. ; DE ANTA, J. M. \& MANZANARES-CÉSPEDES, M. C. Análisis mediante Micro-Ct del ensanchamiento del foramen apical de dientes maduros: Un estudio cadavérico. Int. J. Odontostomat., 14(2):179-182, 2020.

RESUMEN: La revitalización de dientes necróticos ha sido ampliamente estudiada durante la última década y ofrece varias ventajas sobre la endodoncia convencional, tal como la recuperación del sistema inmunitario natural del diente. Los dientes maduros tienen un diámetro de foramen apical (FA) pequeño, lo que podría afectar el crecimiento de tejido en el conducto. Se evaluaron tres métodos para la ampliación del foramen apical en dientes humanos in situ y se evaluó el daño sobre los tejidos duros producidos por las técnicas. Mediante radiografía periapical se calculó la longitud del diente (TL), definida como la longitud desde la parte más coronal de la corona hasta el punto en que la lima abandonó el conducto radicular. En el estudio fueron aleatorizados 44 dientes in situ: Grupo I: instrumentación 0,5 mm coronal a TL; Grupo II: a nivel TL; Grupo III: 0,5 mm más allá de TL. Los dientes fueron instrumentados hasta la lima $\mathrm{K}$ \#80. Las mandíbulas se escanearon en un dispositivo de microCT antes y después del tratamiento. Grupo I: solo el $20 \%$ de los dientes presentaron un diámetro de FA ensanchado, con un aumento de 0,09 mm. No se observó daño a los tejidos duros. Grupo II: el 71,4 \% de los dientes presentaban un FA ensanchado con un aumento de 0,42 mm. El 35,7 \% presentó daño a los tejidos periapicales. Grupo III: el 86,7\% presentó un FA ensanchado con un aumento de 0,43 mm. El 46,7 \% presentó daño a los tejidos periapicales. Todos los grupos presentaron una prevalencia similar de dientes con un espesor de dentina inferior a $1 \mathrm{~mm}$. Todos los incisivos mandibulares presentaban áreas de grosor inferior a $1 \mathrm{~mm}$. La instrumentación $0,5 \mathrm{~mm}$ más allá de TL es la técnica más efectiva, aunque se debe tener especial consideración en aspectos como el debilitamiento de la estructura dentaria.

PALABRAS CLAVE: endodoncia regenerativa, revitalización, dientes maduros, ensanchamiento del foramen apical.

\section{REFERENCES}

Bucchi, C.; Gimeno-Sandig, A. \& Manzanares-Céspedes, C. Enlargement of the apical foramen of mature teeth by instrumentation and apicoectomy. A study of effectiveness and the formation of dentinal cracks. Acta Odontol. Scand., 75(7):488-95, 2017.

Bucchi, C.; Gimeno-Sandig, Á.; Valdivia-Gandur, I.; Manzanares-Céspedes, C. \& de Anta, J. M. A regenerative endodontic approach in mature ferret teeth using rodent preameloblast-conditioned medium. In Vivo, 33(4):1143-50, 2019. 
Ceyhanli, K. T.; Erdilek, N.; Tatar, I. \& Cetintav, B. Comparative microcomputed tomography evaluation of apical root canal transportation with the use of ProTaper, $\mathrm{RaCe}$ and Safesider systems in human teeth. Aust. Endod. J., 40(1):12-6, 2014.

de Souza Filho, F. J.; Benatti, O. \& de Almeida, O. P. Influence of the enlargement of the apical foramen in periapical repair of contaminated teeth of dog. Oral Surg. Oral Med. Oral Pathol., 64(4):480-4, 1987

Del Fabbro, M.; Lolato, A.; Bucchi, C.; Taschieri, S. \& Weinstein, R. L. Autologous platelet concentrates for pulp and dentin regeneration: a literature review of animal studies. J. Endod., 42(2):250-7, 2016.

EIAyouti, A.; Hülber-J, M.; Judenhofer, M. S.; Connert, T.; Mannheim, J. G.; Löst, C.; Pichler, B. J. \& von Ohle, C. Apical constriction: location and dimensions in molars-a micro-computed tomography study. J. Endod., 40(8):1095-9, 2014

Estefan, B. S.; El Batouty, K. M.; Nagy, M. M. \& Diogenes, A. Influence of age and apical diameter on the success of endodontic regeneration procedures. J. Endod., 42(11):1620-5, 2016.

Galler, K. M. \& Widbiller, M. Perspectives for cell-homing approaches to engineer dental pulp. J. Endod., 43(9S):S40-S45, 2017.

Galler, K. M.; Widbiller, M.; Buchalla, W.; Eidt, A.; Hiller, K. A.; Hoffer, P. C. \& Schmalz, G. EDTA conditioning of dentine promotes adhesion, migration and differentiation of dental pulp stem cells. Int. Endod. J., 49(6):581-90, 2016.

He, L.; Kim, S. G.; Gong, Q.; Zhong, J.; Wang, S.; Zhou, X.; Ye, L.; Ling, J. \& Mao, J. J. Regenerative endodontics for adult patients. J. Endod., 43(9S):S57-S64, 2017.

Jara, C. M.; Hartmann, R. C.; Böttcher, D. E.; Souza, T. S.; Gomes, M. S. \& Figueiredo, J. A. P. Influence of apical enlargement on the repair of apical periodontitis in rats. Int. Endod. J., 51(11):1261-70, 2018.

Kus, tarci, A.; Akpinar, K. E.; Sümer, Z.; Er, K. \& Bek, B. Apical extrusion of intracanal bacteria following use of various instrumentation techniques. Int. Endod. J., 41(12):1066-71, 2008.

Laureys, W. G. M.; Cuvelier, C. A.; Dermaut, L. R. \& De Pauw, G. A. M. The critical apical diameter to obtain regeneration of the pulp tissue after tooth transplantation, replantation, or regenerative endodontic treatment. J. Endod., 39(6):759-63, 2013.

Lin, J.; Zeng, Q.; Wei, X.; Zhao, W.; Cui, M.; Gu, J.; Lu, J.; Yang, M. \& Ling, J. Regenerative endodontics versus apexification in immature permanent teeth with apical periodontitis: a prospective randomized controlled study. J. Endod., 43(11):1821-7, 2017.

Lolato, A.; Bucchi, C.; Taschieri, S.; El Kabbaney, A. \& Del Fabbro, M. Platelet concentrates for revitalization of immature necrotic teeth: a systematic review of the clinical studies. Platelets, 27(5):383-92, 2016.

Lucena, C.; López, J. M.; Martín, J. A.; Robles, V \& GonzálezRodríguez, M. P. Accuracy of working length measurement: electronic apex locator versus cone-beam computed tomography. Int. Endod. J., 47(3):246-56, 2014

Meschi, N.; EzEldeen, M.; Torres Garcia, A. E.; Jacobs, R. \& Lambrechts, P. A retrospective case series in regenerative endodontics: trend analysis based on clinical evaluation and 2and 3-dimensional radiology. J. Endod., 44(10):1517-25, 2018.

Murray, P. E.; Garcia-Godoy, F. \& Hargreaves, K. M. Regenerative endodontics: a review of current status and a call for action. J. Endod., 33(4):377-90, 2007.

Olivieri, J. G.; Stöber, E.; García Font, M.; González, J. A.; Bragado, P.; Roig, M. \& Duran-Sindreu, F. In vitro comparison in a manikin model: increasing apical enlargement with $\mathrm{K} 3$ and $\mathrm{K} 3 \mathrm{XF}$ rotary instruments. J. Endod., 40(9):1463-7, 2014.

Paryani, K. \& Kim, S. G. Regenerative endodontic treatment of permanent teeth after completion of root development: a report of 2 cases. J. Endod., 39(7):929-34, 2013.

Rodrigues, R. C. V.; Zandi, H.; Kristoffersen, A. K.; Enersen, M.; Mdala, I.; Ørstavik, D.; Rôças, I. N. \& Siqueira Jr., J. F. Influence of the apical preparation size and the irrigant type on bacterial reduction in root canal-treated teeth with apical periodontitis. J. Endod., 43(7):1058-63, 2017.
Saoud, T. M.; Martin, G.; Chen, Y. H. M.; Chen, K. L.; Chen, C. A.; Songtrakul, K.; Malek, M.; Sigurdsson, A. \& Lin, L. M. Treatment of mature permanent teeth with necrotic pulps and apical periodontitis using regenerative endodontic procedures: a case series. J. Endod., 42(1):57-65, 2016.

Sedgley, C. M. \& Messer, H. H. Are endodontically treated teeth more brittle? J. Endod., 18(7):332-5, 1992.

Siqueira Jr., J. F. Microbial causes of endodontic flare-ups. Int. Endod. J., 36(7):453-63, 2003.

Tsesis, I.; Blazer, T.; Ben-Izhack, G.; Taschieri, S.; Del Fabbro, M.; Corbella, S. \& Rosen, E. The precision of electronic apex locators in working length determination: a systematic review and meta-analysis of the literature. J. Endod., 41(11):1818-23, 2015.

Wei, X.; Hu, B.; Peng, H.; Tang, M. \& Song, J. The incidence of dentinal cracks during root canal preparations with reciprocating single-file and rotary-file systems: a meta-analysis. Dent. Mater. J., 36(3):243-52, 2017.

Widbiller, M.; Eidt, A.; Hiller, K. A.; Buchalla, W.; Schmalz, G. \& Galler, K. $M$. Ultrasonic activation of irrigants increases growth factor release from human dentine. Clin. Oral Investig., 21(3):879-88, 2017.

$\mathrm{Xu}, \mathrm{Q}$. \& Li, Z. Regenerative endodontic treatment of a maxillary mature premolar. Case Rep. Dent., 2018:5234136, 2018.

Yaylali, I. E.; Teke, A. \& Tunca, Y. M. The effect of foraminal enlargement of necrotic teeth with a continuous rotary system on postoperative pain: a randomized controlled trial. J. Endod., 43(3):359-63, 2017.

Corresponding author:

Prof. Dr. Josep Maria de Anta

Human Anatomy and Embryology Unit

Department of Pathology and Experimental Therapeutics

Universitat de Barcelona

Barcelona 08907

SPAIN

Email: janta@ub.edu

Received: 10-09-2019

Accepted: 08-11-2019 